\title{
Urinary Bladder Mass Due To Chronic Lymphocytic Leukaemia
}

\author{
Manoj P Rai, ${ }^{1}$ Prabhjot S Bedi, ${ }^{2}$ Edwin B Marinas, ${ }^{3}$ Supratik Rayamajhi ${ }^{1}$
}

'Internal Medicine, Michigan State University / Sparrow Hospital, Lansing, Michigan, United States of America ${ }^{2}$ Internal Medicine, UPMC East, Monroeville, Pennsylvania, USA ${ }^{3}$ Department of Pathology, Sparrow Health System, Lansing, Michigan, USA

\section{Correspondence to} Dr Manoj P Rai, manojrai029@gmail.com

PSB and SR contributed equally.

Accepted 1 January 2018

\section{DESCRIPTION}

A 66-year-old man was diagnosed with chronic lymphocytic leukaemia (CLL) in November 2014. At diagnosis, his lymphocyte count was $169.66 \times 10^{9} / \mathrm{L}$ (table 1 ). The fluorescent in situ hybridisation (FISH) panel revealed $13 \mathrm{q}$ deletion, but there was no evidence of $17 \mathrm{p}$ deletion, $11 \mathrm{q}$ deletion or $\mathrm{t}(11 ; 14)$. He then received four cycles of bendamustine and rituximab, and at the end of the treatment complete blood count showed a lymphocyte count of $1.01 \times 10^{9} / \mathrm{L}$ (table 1), and an interval bone marrow biopsy showed only small lymphoid aggregate suggestive of partial response. ${ }^{1}$ In June 2017, his lymphocyte count was found to be elevated at $14.5 \times 10^{9} / \mathrm{L}$ (table 1). An immunophenotypic analysis of the peripheral blood demonstrated approximately $78 \%$ lymphocytes and 0.5\% mature CD14-positive monocytes. A predominant monoclonal $\mathrm{B}$ cell population was identified, comprising approximately $85 \%$ of lymphocytes and $67 \%$ of the processed specimen. It was positive for CD5, CD19, CD20, CD23, CD45, human Leukocyte Antigen - antigen D Related (HLA-DR) and surface kappa light chain, and negative for CD10, CD22, CD38 and FMC7. The remainder of lymphocytes included approximately 7\% $\mathrm{T}$

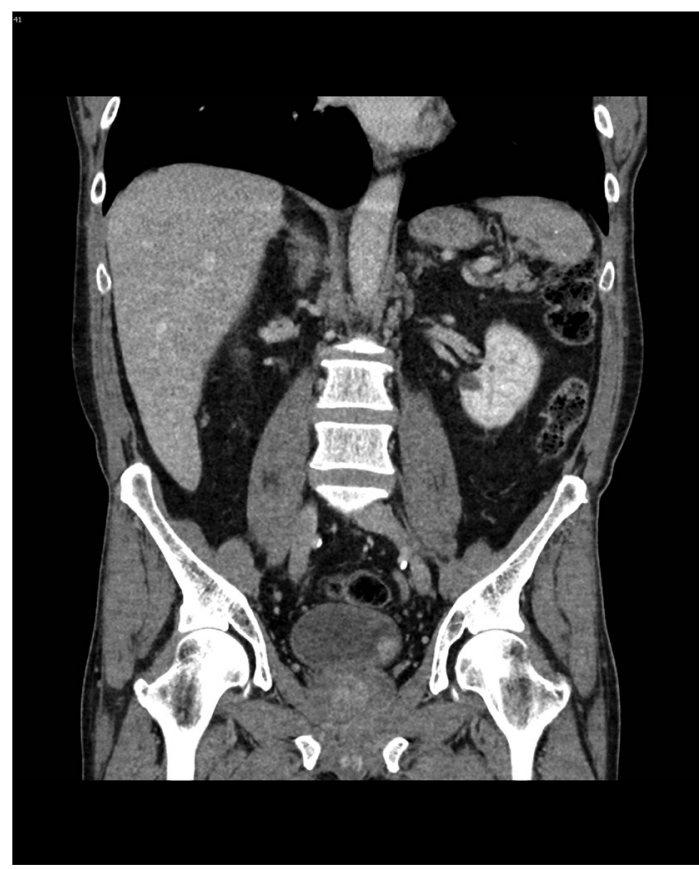

Figure 1 Intravenous contrast-enhanced CT in nephrographic phase showing enhancing mass in urinary bladder.

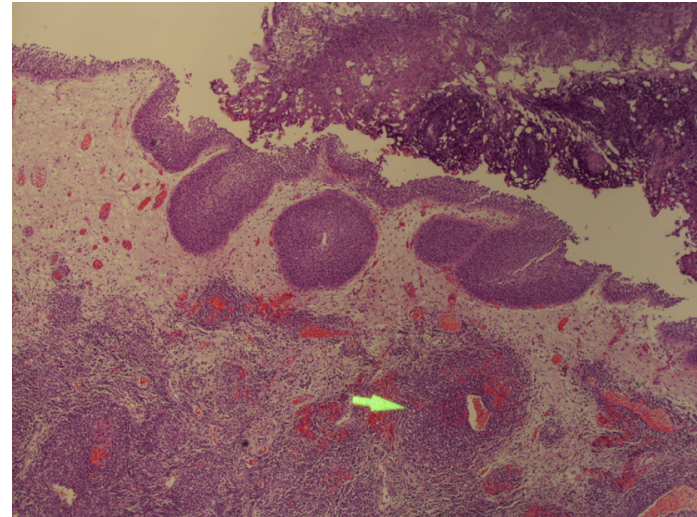

Figure 2 Histopathology (H\&E stain) of the urinary bladder mass showing low-grade lymphoproliferative disorder characterised by a diffuse proliferation of small mature lymphocytes associated with a few large lymphoid cells and rare eosinophils.

cells with a CD4/CD8 ratio of 1.3 . In summary, a predominant partially CD5-positive, kappa-restricted monoclonal B cell population was identified, immunophenotypically similar to that identified in previous bone marrow biopsy except that partial CD5 expression was identified. The FISH panel revealed $13 \mathrm{q}$ deletion with no evidence of $17 \mathrm{p}$ deletion, $11 \mathrm{q}$ deletion or $\mathrm{t}(11 ; 14)$, similar to the results at the time of diagnosis. The patient was kept on surveillance as there were no cytopaenias and no other indication of treatment. Three months later he presented to the emergency department with haematuria. CT of the abdomen/pelvis showed a mass in the urinary bladder. CT urography showed an intravesical mass in the left wall bladder with bladder wall infiltration, and additional intraluminal soft tissue mass projecting in and about the region of the ureteral entry through the ureterovesicular junction at the bladder trigone (figure 1). Transurethral resection of bladder tumour was performed, and the mass was $2.4 \times 1.0 \times 0.5 \mathrm{~cm}$ in size. Histopathology showed low-grade lymphoproliferative disorder characterised by a diffuse proliferation of small mature lymphocytes associated with a few large lymphoid cells and rare eosinophils (figure 2). Immunohistochemical analysis showed small neoplastic lymphocytes positive for CD20, CD23, CD79a, CD5, BCL2 and BCL6 with weak intensity, and CD43. The neoplasm showed a Ki-67 proliferation fraction of approximately $20 \%$. A few reactive plasma cells exhibited polyclonal staining pattern for kappa and lambda immunoglobulin light chains. 


\begin{tabular}{|c|c|c|c|c|}
\hline $\begin{array}{l}\text { Complete blood count } \\
\text { with differential }\end{array}$ & $\begin{array}{l}\text { At } \\
\text { diagnosis }\end{array}$ & $\begin{array}{l}\text { End of } \\
\text { cycle } 1\end{array}$ & $\begin{array}{l}\text { End of } \\
\text { cycle } 4\end{array}$ & $\begin{array}{l}\text { At } \\
\text { progression }\end{array}$ \\
\hline $\begin{array}{l}\text { White blood cells }(\text { WBC) } \times \\
109 / \mathrm{L} \times\end{array}$ & 176 & 56.7 & 3.1 & 53.1 \\
\hline $\begin{array}{l}\text { Red blood cells }(\mathrm{RBC}) \times \\
106 / \mathrm{LL}\end{array}$ & 1.11 & 2.79 & 4.05 & 3.72 \\
\hline Haemoglobin(Hb) g/dL & 3.8 & 9.3 & 13.8 & 13.4 \\
\hline Haematocrit (Hct) \% & 14.6 & 29.4 & 40.3 & 39.3 \\
\hline $\begin{array}{l}\text { Mean corpusular Volume } \\
\text { (MCV) fL }\end{array}$ & 132 & 105 & 100 & 106 \\
\hline $\begin{array}{l}\text { Mean corpuscular } \\
\text { hemoglobin }(\mathrm{MCH}) \mathrm{pg}\end{array}$ & 34.2 & 33.3 & 34.1 & 36 \\
\hline $\begin{array}{l}\text { Mean corpuscular } \\
\text { hemoglobin concentration } \\
(\mathrm{MCHC}) \mathrm{g} / \mathrm{dL}\end{array}$ & 26 & 31.6 & 34.2 & 34.1 \\
\hline Platelet Count $\times 109 / \mathrm{L}$ & 30 & 23 & 216 & 186 \\
\hline Neutrophils \% & 1.9 & 1.1 & 41.4 & 51.9 \\
\hline Lymphocytes \% & 96.4 & 97 & 32.2 & 27.4 \\
\hline Monocytes \% & 1.6 & 1.8 & 16.2 & 17.1 \\
\hline Eosinophils \% & 0.1 & 0.1 & 7.3 & 2.7 \\
\hline Basophils \% & 0 & 0 & 2.9 & 0.9 \\
\hline $\begin{array}{l}\text { Absolute neutrophils } \times \\
109 / \mathrm{L}\end{array}$ & 3.344 & 0.59 & 1.3 & 27.55 \\
\hline $\begin{array}{l}\text { Absolute lymphocytes } \times \\
109 / \mathrm{L}\end{array}$ & 169.66 & 54.98 & 1.01 & 14.5 \\
\hline $\begin{array}{l}\text { Absolute monocytes } \times \\
109 / \mathrm{L}\end{array}$ & 2.816 & 1.02 & 0.51 & 9.08 \\
\hline $\begin{array}{l}\text { Absolute eosinophils } \times \\
109 / \mathrm{L}\end{array}$ & 0.176 & 0.08 & 0.23 & 1.4 \\
\hline Absolutebasophils $\times 109 / \mathrm{L}$ & 0 & 0.02 & 0.09 & 0.4 \\
\hline
\end{tabular}

\section{Learning points}

- Chronic lymphocytic leukaemia (CLL) causing bladder mass is rare and to date only a few cases have been reported, but in a patient with CLL presenting with bladder mass a high index of suspicion should be placed for CLL bladder infiltration.

- In patients with a diagnosis of CLL, a close surveillance is required since there is a risk of recurrence or progression.

Rare plasma cells were positive for CD138. CD3 highlighted a small population of $\mathrm{T}$ cells. The above findings were consistent with CLL/small lymphocytic lymphoma. A positron emission tomography (PET)-CT was obtained. The PET part was unremarkable, while the CT showed an increased number of small lymph nodes in the mesentery as well as in the upper retroperitoneum. CLL in the urinary bladder is a rare manifestation.

Contributors MPR prepared the manuscript (case and the short discussion). PB assisted with the manuscript revision. EBM provided the pathology slides and edited the manuscript. SR revised the paper.

Competing interests None declared.

Patient consent Obtained.

Provenance and peer review Not commissioned; externally peer reviewed.

(c) BMJ Publishing Group Ltd (unless otherwise stated in the text of the article) 2018. All rights reserved. No commercial use is permitted unless otherwise expressly granted.

\section{REFERENCE}

1 Hallek M, Cheson BD, Catovsky D, et al. Guidelines for the diagnosis and treatment of chronic lymphocytic leukemia: a report from the international workshop on chronic lymphocytic leukemia updating the national cancer institute-working group 1996 guidelines. Blood 2008;111:5446-56.

Copyright 2017 BMJ Publishing Group. All rights reserved. For permission to reuse any of this content visit

http://group.bmj.com/group/rights-licensing/permissions.

BMJ Case Report Fellows may re-use this article for personal use and teaching without any further permission.

Become a Fellow of BMJ Case Reports today and you can:

- Submit as many cases as you like

- Enjoy fast sympathetic peer review and rapid publication of accepted articles

- Access all the published articles

- Re-use any of the published material for personal use and teaching without further permission

For information on Institutional Fellowships contact consortiasales@bmjgroup.com

Visit casereports.bmj.com for more articles like this and to become a Fellow 